\title{
The Public-Private Divide in Ethiopian Higher Education: Issues and Policy Implications
}

\author{
Mulu Nega \\ Higher Education Policy and Quality Assurance, Institute of Educational Research, Addis Ababa University, Ethiopia
}

Copyright $\bigcirc 2017$ by authors, all rights reserved. Authors agree that this article remains permanently open access under the terms of the Creative Commons Attribution License 4.0 International License

\begin{abstract}
This article explores the current issues on the public-private divide in the Ethiopian higher education landscape and their policy implications. It critically examines issues related to legal and regulatory frameworks in order to understand the public-private divide in the Ethiopian higher education context. The article is based on two premises. The first pertains to the idea that public and private higher education providers are commonly required to meet the quality and relevance imperatives of their salient stakeholders as stipulated in the higher education proclamation. The second concerns the argument that an enabling policy and legal framework is crucial for the private higher education sector to play a key role in addressing the social demand for higher education, and thereby contribute for the socio-economic development of a country. This article draws mainly on secondary sources of data from official government documents including policies, proclamations, pertinent national and international research reviews, national and organizational level plans and strategies, statistical abstracts and reports as well as key informant interviews to analyze the issue under study. The findings revealed that the private higher education providers are playing a significant role in addressing the unmet social demand for higher education through increasing access and thereby creating employment opportunities. However, the existing playground/rule of the game is not fairly treating both public and private providers in terms of student admission, quality regulation and other policy incentives. It is argued that the government should create a fair and robust legal and regulatory framework to maximize the benefits of both public and private providers in terms of improving access, relevance, and quality education. Finally, policy implications for improvement of the current status of private providers are suggested based on the findings.
\end{abstract}

Keywords Higher Education, Legal Framework, Public, Private, Policy, Quality, Relevance, Stakeholder

\section{Background}

Higher education has long been regarded as a public good in terms of producing enormous externalities, benefiting not only the individual, but also the society at large. The social benefits/externalities of higher education cover economic, political, social, cultural and technological aspects such as economic growth through innovation and technological changes, increased productivity and tax revenues, political stability and social cohesion that are widely acknowledged as core reasons for countries to invest on higher education. This paradigm has been influencing public laws and policies in higher education throughout the world for a long time.

However, many higher education systems across the globe have gone through significant changes in relation to sources of funding, governance, institutional arrangement and regulation over the past several decades. The main driving forces for such changes include, among others, the increasing social demand for higher education coupled with inadequate government funding, the rise of market ideology and competitiveness, and new technologies. These developments challenge the long-cherished and well established view of higher education as a public good and the way it was governed, provided, and financed, particularly the overwhelmingly public responsibility for higher education. In relation to the market paradigm, discussions on the private good focuses on the individual benefits of higher education that include market benefits such as higher earnings, increased employability \& social status of graduates, increased productivity and non-market benefits, among others. This paradigm has created conducive environment for the creation and growth of different forms of private higher education providers across the globe. Though private higher education has been common worldwide for many decades, modern private higher education was a phenomenon of the late $20^{\text {th }}$ century for Africa in general and sub-Saharan Africa in particular and Ethiopia is not an exception.

Overall, the higher education landscape of many developed and developing countries has now changed and characterized by the public-private dynamism. The public-private divide has been a fundamental area of debate 
in the analysis of higher education organizations, national higher education systems and their political economy $[1 ; 2]$. The debates on the distinction between public and private spheres are grounded on issues related to legal ownership and responsibilities, role of the state, and the social character of the outcome of higher education, i.e., what constitutes the public versus the private good. These issues have profound implications to the role of legal/policy, regulatory and governance arrangements for a given higher education system.

Hence, this article aims to explore the current issues on the public-private divide in the Ethiopian higher education landscape and their policy implications.

\section{The Research Agenda}

This article aims to examine the issues and challenges, particularly the influence of the legal and regulatory framework on the public-private divided in the Ethiopian higher education landscape. It is based on two premises. The first pertains to the idea that public and private higher education providers are commonly required to meet the quality and relevance imperatives of their salient stakeholders as stipulated in the higher education proclamation. The second concerns the argument that an enabling legal and policy framework is crucial for the private higher education sector to play a key role in addressing the social demand for higher education, and thereby contribute for the socio-economic development of a country. Accordingly, the article attempts to answer the following questions:

- What are the major issues/challenges in the public private divide in the Ethiopian higher education landscape?

- How do the existing legal and policy frameworks influence the divide?

- What are the implications to maintain a balance between the public and private spheres in addressing the unmet social demand for higher education?

\section{Theoretical Framework}

The focus of this article is on the current issues about the public-private divide in higher education. This section presents a brief overview of the key concepts, debates, theoretical assumptions and factors that underlie discussions about the public-private divide in higher education.

\subsection{The Concept of Public and Private Good in Higher Education}

The public-private distinction in higher education has been a fundamental area of debate for several decades. It has also been a matter of considerable scholarly interest since the mid-1980s, fuelled in part by the growth of private sectors of higher education in many areas of the globe [3]. The major issues of the current debates are related to what constitutes the public versus the private good that ranges from economic and legal ownership to social/cultural characteristics of the goods.

Traditional conceptualizations of the public-private distinctions in higher education were rooted in the perspectives of liberal economics and liberal political philosophy. Both perspectives treat public and private as mutually exclusive concepts, in which the economic notion associates 'public' with not $-\mathrm{a}$ natural market and the political philosophy associates 'public' with government or state [4]. In liberal economics, public goods are conceptualized as non-rivalrous and non-excludable goods, whereas private goods refer to rivalrous and excludable goods [4]. Accordingly, public goods are non-rivalrous, because they can be consumed by any number of people without being depleted and they are non-excludable, because their benefits cannot be confined to individual buyers [4]. In liberal political philosophy, the public is associated with government or state (i.e. goods that are collectively produced and/or consumed), whereas any non-state ownership or the market refers to private. More specifically, the term 'private' relates to market-type coordination mechanisms: price, competition, decentralized decision-making [5].

From the liberal economics point of view, for the most part, higher education is a natural private good and should be marketized, whereas in liberal political philosophy higher education is a public good [4]. The liberal economics view tends to downplay the potential for collective goods in higher education and the liberal political philosophy underestimates the role of markets. From the liberal economics perspective, the main trust in the market is based on the fundamental tenet that competition creates efficiencies, cost savings and productivity gains [5].

However, in recent times scholars have been criticizing the dualistic nature of the private-public divide in higher education based on the social character of the outcomes as follows.
In determining the nature of the goods, public or private, whether or not the goods are market-produced is much more important than whether or not they are state or non-state sector produced. Though state institutions are - arguably - more open to policy making than are privately owned institutions, both state and private sector institutions produce public and private goods, and both sectors are accessible to policy. Ownership and policy are only two of the inputs that determine higher education [4].

In this line of argument, public goods are conceptualized as goods that have a significant element of non-rivalry and non-excludability (collective goods and externalities), and goods that are made broadly available across populations, 
whereas goods without such attributes are private goods. The public and private goods are not necessarily zero sum, but rather they are often inter-dependent, in that the production of one kind of good provides conditions necessary to the other [4]. Regarding higher education, private and public goods are produced in the same organizations committed to education, research and community services, though they are heterogeneous to each other. In other words, the core missions of a university- research and teaching are associated with both public and private goods [6]. Accordingly, the research output of universities-knowledge is considered as predominantly public good, though there is a moment of excludability and rivalrousability when it is first created and disseminated. Similarly, teaching in elite vocational and university educational institutions where there is rising scarcity of places is considered private, whereas teaching in less selective universities (e.g. in equally resourced universities) is considered as public good. This shows that higher education produces a complex and variable mix of public and private goods, whether its ownership is exclusively public, or mixed, or exclusively private.

The arguments in the preceding paragraphs point to the issues that the debates on the public-private distinction resonate on whether there are ideal types of public and private goods in higher education and the underlying differentiation factors between the two sectors. As multi-dimensional and multi product organizations, higher education institutions acquire elements of publicness and privateness regardless of how they are governed, financed, owned and functioned. To put it differently, both public and private higher education organizations allows for a private as well as a public benefit on investment in a varying degree, which results in a blurred border between the two sectors $[7 ; 8]$. Hence, the issue here is what determines the public-private distinction in higher education, which is briefly reviewed in the section that follows.

\subsection{Factors that Determine the Publicness or Privateness of Higher Education Institutions}

The public-private divide in higher education varies across countries. In fact the balance in the public- private mix is one of the key elements that differentiate institutions and national system of higher education. Many of the discussions on what determines the publicness and privateness of higher education dwell on the way higher education is owned, provided, financed and governed.

Many scholars argue that the publicness or privateness of higher education in most of the world is determined by several factors including, among others, institutional mission, source of funding, orientation, legal and official definition, type of governance and form of control [1, 9, 2, 10, 8 and 11]. Similarly, another scholar noted that factors such as the position of the state, ownership, governance, financial resources, affiliation and function can be invariably combined for determining whether institutions are private or public [12]. In this regard, emphasizing on the state as a powerful factor, one scholar argues that 'while public sectors can be regarded, directly or indirectly, as creatures of the state, the state also to a considerable extent molds the conditions of existence for privately controlled institutions.'[13]. In other words, the amount and kind of higher education provided by government (ownership and funding) is the single most important determinant of the size and character of private higher education in each national system. Accordingly, three basic structural patterns of public-private differentiation have been identified, viz., 1) mass private and restricted public sectors, which is dominated by massive private sector with restricted public sectors; 2) parallel public and private sectors, in which both the private and public sectors play a role in providing education services and it is characterized by a symmetrical relationship of the two sectors; 3 ) comprehensive public \& peripheral private sectors, which refers to the peripheral private sector in which the private sector plays a very limited role[1]. Regarding mass private sector and parallel, particularly in the case of for-profit institutions, the state implements strict regulation including detailed and specific requirements for relevant and quality curricula; pedagogical effectiveness, degrees and even classroom conduct under the pretext of consumer protection [13].

Other scholars focus on the importance of legal and regulatory framework as an overarching variable in determining the publicness and privateness of higher education institutions. It is, for example, argued that legislation and regulations define the priorities and policies that not only enact needed changes, but also help shape value and stakeholder perceptions [14]. Similarly, another author maintained that in its constitutive guise, among other definitions the law determines which organizations are to be deemed private and which public, and seeks to delineate the consequences that follow from each organizational nature, such as the kind of law applicable to each one, their form of access to staff and other resources, and the manner of their interaction with the government [3]. In most cases, the growth of private higher education is linked to the varying degrees of the permissiveness of the legal and regulatory framework, among others [15]. In other words, some of the differentiation factors for publicness and privateness such as governance, financing and ownership depend on the way in which the legal framework defines what is public and what is private higher education. This suggests the centrality of legal and policy frameworks in determining whether higher education organizations are private or public in addition to factors such as the ownership and responsibilities, financial resources, affiliation and the social character of the outcomes of higher education.

The debates on the public-private distinction have resulted in the typology and taxonomic description of the functions of private higher education across the globe. In this regard, three roles of private higher education have been identified 
namely, private higher education institution that are supposed to provide: 1) better services-elite institutions; 2) different services such as religious providers, and 3) more higher education and absorb demand that is not met by public providers [1]. Similarly, private higher education institutions can be described in terms of the benefits they generate viz., distinctiveness from the public sector in terms of program offerings and student experience; providing an alternative based on heightening the quality of education through admission and teaching standards; providing access to students who otherwise may not be qualified to attend public universities or denied due to capacity or geographic constraints $([16,17]$.

In sum, the distinction between public and private higher education based on factors such as governance, financing and ownership is blurred. It is argued that the law, insofar as it defines higher education as either public or private, can be considered as the only unambiguous criterion for the distinction between the two spheres compared to other factors [10]. In this regard, another scholar on his part noted that it is difficult to even discuss about private or public higher education without beginning the analysis with a reference, explicit or not, as to which institutions the law classifies on either sphere [3].

\subsection{Overarching Issues Regarding the Public-Private Distinction}

The arguments in the preceding paragraphs suggest that private and public institutions are part of a common institutional setting in which the legal and policy environment plays a role, whether implicitly or explicitly, in shaping the dynamics between the two sectors. This suggests that both public and private higher education providers are accessible to public policies and regulations related to their provision, funding, credibility, quality and relevance of education. Hence, the rule of the game should be on the relevance and quality of goods and services provided by both public and private higher education providers regardless of the ownership, source of funding and governance. In this regard, one scholar argues noted the following:

Higher education institutions may be required to operate within the framework established by public authorities but as long as they do so, it is difficult to argue that they have to be publicly run and financed. To me, the issue is not whether higher education institutions are public or private, but whether they are of good quality, are subject to quality assessment, offer programmes leading to recognized qualifications, offer equal access and ensure academic freedom for staff and students. To paraphrase two dictums of a now outmoded ideology, what matters is not the ownership of the means of education, but whether the cat catches mice [18]
The main issue is thus the extent to which the stakeholders/the public benefited from relevant and quality higher education services regardless of the ownership. This requires ensuring a robust legal and policy framework that fairly treats and incentifies both public \& private sectors. It also involves feedback mechanisms, shared governance through negotiated \& well defined relationships among actors \& organizations, building trust and accountability among actors and organizations, collaboration and complementarity between the two sectors. In this regard, the aim of the government should be to achieve a legal and regulatory system that provides the right balance between protecting the public and encouraging private providers to invest [19]. In other words, where public policy allows private providers, the primary motive of the legal and regulatory system should be on consumer protection; enabling students and parents to make informed decision regarding their choice of higher education institutions and monitoring the relevance, quality and financial matters of private providers. This suggests that the extent to which the private higher education institutions comply with the quality and relevance requirements stipulated in government legislation and regulatory laws has implications to their operation and survival.

The class divide in higher education is another issue that has to be taken into account in discussing about the public-private distinction. It is related to class inequality in access to and type of higher education attended due to selective admission and financial affordability of higher education. In a meritocratic and highly stratified higher education system such as USA, class differences in access to selective college destinations become more prominent [20]. In such market driven systems, private higher education institutions only absorb those students who can afford their prices. In this context, the ability to pay for education is more consequential factor than college preparedness for determining college access and choice [21]. The role of the state in market-driven inequity is financing access to the needed through student loans and grants [20]. In other higher education systems such as Brazil, the very selective entrance examinations for the public sector which is free of charges, but small has been a factor of inequity [22]. This implies that the extent to which private higher education expands the class divide depends on contextual factors and legal frameworks in which they operate.

Though there are many factors that underlie the public-private distinction, this article focuses on the major issues/challenges and the influence of the legal/policy and regulatory framework on the public-private divide in higher education. The legal/policy framework refers to the legislative and regulative aspects through which governments influence the operation of an organization. In the Ethiopian context, this includes the higher education proclamation, education and training policy, Science, technology and innovation policy, sets of rules and 
regulations that govern and influence the operation of public and private higher education institutions. The regulators include government organizations such as HERQA, ESC, Ministry of Education, Ministry of Science and Technology that poses some pubic authority to regulate and ensure compliance with laws, regulations, and established rules.

\section{Methods}

This article depends mainly on secondary source of data and key informant interviews. The data come from document mining include government policies, higher education proclamations, sector development programs; national and organizational level plans and strategies (GTP), circulars from the Ministry of Education, annual statistical abstracts and quality audit reports published by HERQA. Pertinent national and international research reviews, recent research conducted on public and private higher education institutions, information about ESC and HERQA were also sufficiently consulted to generate the required data. Ten interviews were also conducted with representatives from the Ministry of Education, private and public higher education institutions of Ethiopia. During analyses, an attempt was made to validate the data collected from different sources.

\section{Findings}

Major results of data analyses concerning the public-private divide in the Ethiopian higher education context are discussed in this section. It begins with a scanning of the changes in the higher education land scape, followed by the analysis of the issues and challenges in the public-private divide in higher education. Finally, data on the influence of the legal/policy and regulatory framework on the public-private distinction in the Ethiopian higher education context are analyzed.

\subsection{Changes in the Ethiopian Higher Education Environment: Opportunities}

Analysis of the documentary evidences shows that there have been rapid changes in the social environment of the Ethiopian higher education over the past two decades. These changes include, among others demographic conditions, political and economic aspects. As indicated in Table1, there are changes in the demographic characteristics of the population with a fast growing school age population that accounts for about $50 \%$ of the total population. Similarly, there have been changes in the political environment that set the country's vision toward becoming a middle income economy by the year 2025 through sustaining a rapid (two digit) economic growth (see Table 1 below).
Table 1. The changes in the Ethiopian higher education environment

\begin{tabular}{|c|l|}
\hline \multirow{2}{*}{$\begin{array}{c}\text { Demographic } \\
\text { conditions }\end{array}$} & $\begin{array}{l}\text { About } 80 \% \text { economically active population (10 } \\
\text { years \& above) } \\
\text { A fast growing school age population (5-24 } \\
\text { years)- about 50\%, }\end{array}$ \\
\hline \multirow{3}{*}{ Political aspects } & $\begin{array}{l}\text { A shift from planned economy to market } \\
\text { economy } \\
\text { Policy and legal framework for HE } \\
\text { Ethiopia's vision towards becoming a middle } \\
\text { income economy by the year 2025 }\end{array}$ \\
\hline \multirow{2}{*}{ Economic aspects } & $\begin{array}{l}\text { Rapid economic development with two digit } \\
\text { economic growth } \\
\text { The current shift from agricultural-led to } \\
\text { industrial led economy }\end{array}$ \\
\hline
\end{tabular}

The changes in the higher education environment have brought huge demand for human resource capacity building. The role of higher education in human resource development has been identified as one of the key pillars in the socio-economic transformation process of the country across all the subsequent government development plans including GTP [23]. This has resulted in the rapid change of the higher education landscape. These changes include, among others changes in size and shape-the increase in the number of public universities and the introduction of private institutions; participation rate; governance and management, finance, a shift in focus in favor of science and technology fields, and establishment of quality regulatory bodies. These changes in the higher education landscape have resulted in a rapid institutional and enrolment expansion over the last 15 years (see the chart below).

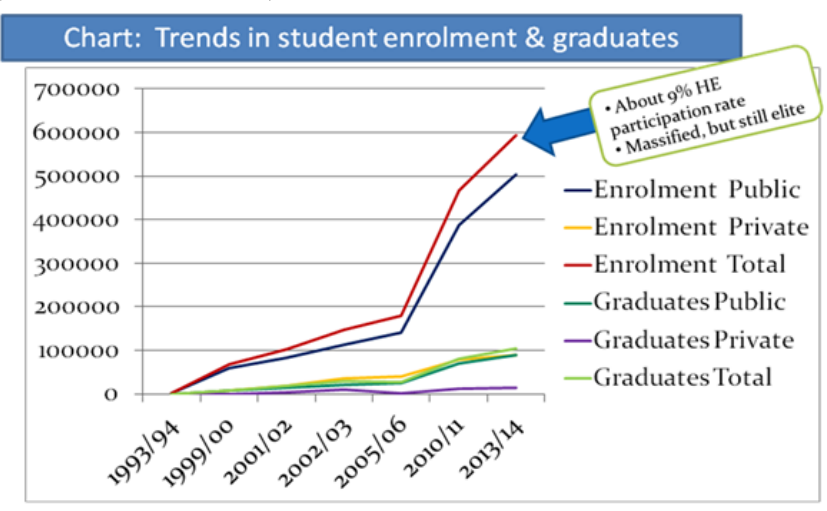

Figure 1. Trends in student enrolment $\&$ graduates

With regard to expansion, the number of public universities increased from 2 in 1991/92 to 36 in 2014/15 at national level, and from less than $4 \%$ of higher education participation rate in 1999 to about 9\% in 2014/15 [24]- rapid expansion with increasing social demand, but still elite. The private higher education institutions have increased from 3 in 1996 to about 100 institutions in 2014/15 (4 of them are universities), and from less than $14 \%$ of higher education enrolments in 1999 to about $15.4 \%$ for undergraduate in $2014 / 15$ [24]. In 2014/15, female students account $34.7 \%$ of the total undergraduate enrolment and $33.1 \%$ of the enrolment in public higher education institutions. In private higher education institutions, female participation accounts 
$43.7 \%$ of the undergraduate enrolment. This shows that private higher education institutions have been playing significant role in addressing the unmet social demand for access to higher education and human resource needs of the country over the past two decades. However, the share of private higher education institutions from the total higher education enrolment $\&$ graduate rates is smaller, though their number surpasses that of the public ones. This suggests that the private higher education institutions play a peripheral role according to Geiger's classification. This raises the question why the higher education enrolment and graduates share of the private sector is lower than the public sector, despite the huge social demand for access to higher education? The issues on this and the challenges underlying the public-private divide in the Ethiopian higher education are explored and analyzed in the subsection that follows.

\subsection{The Major Issues and Challenges Underlying the Public-Private Divide in the Ethiopian Higher Education Landscape}

The findings in the preceding section show that private higher education institutions have been playing significant role in improving access to higher education and the human resource development needs of the country. However, results of analysis of the documentary evidences indicate that private higher education institutions are constrained by a multitude of problems and challenges related to student admission, quality, policy incentives and regulatory frameworks compared to the public ones (see Table2 below).

Table 2. Issues/challenges underlying the public- private divide

\begin{tabular}{|c|c|}
\hline Public HEIs: & Private HEIs: \\
\hline $\begin{array}{l}\text { Established by regulation } \\
\text { Are not subject to } \\
\text { accreditation }\end{array}$ & $\begin{array}{l}\text { Have to pass through rigorous } \\
\text { accreditation processes by HERQA } \\
\text { Are not allowed to operate without } \\
\text { licenses }\end{array}$ \\
\hline $\begin{array}{l}\text { Admission- MoE assigns } \\
\text { students } \\
\text { Best student number }\end{array}$ & $\begin{array}{l}\text { Demand absorbing- cater for excess } \\
\text { demand from public universities } \\
\text { Compete to admit only a tiny proportion } \\
\text { of all students and mostly from low } \\
\text { performing applicants- challenge to get } \\
\text { best students }\end{array}$ \\
\hline $\begin{array}{l}\text { Fully funded by } \\
\text { government including } \\
\text { research funding } \\
\text { Not for profit making }\end{array}$ & $\begin{array}{l}\text { No government funding or subsidy in } \\
\text { the form of student loans, student or } \\
\text { institutional grants } \\
\text { For-profit and non-profit } \\
\text { Their survival heavily depend on } \\
\text { students tuition fees }\end{array}$ \\
\hline
\end{tabular}

As shown in Table2 above, unlike the public ones, private higher education institutions are subject to accreditation by the Higher Education Relevance and Quality Agency (HERQA). This indicates that private higher education institutions cannot operate without accreditation license from the Ministry of Education, whereas public higher education institutions are established by the council of Ministers and allowed by law to open and run programs without accreditation. This suggests that there is differential treatment of the public and private sector under the same law. Regarding the legal framework, one of the interviews from the private institutions noted the following:

The establishment of private higher education institutions appears to be more demanding and less bureaucratic. Private higher education institutions are required to demonstrate strict compliance with the directives issued by the Ministry of Education in terms of students admissions; ensuring the minimum quality standards in terms of staffing, facilities, leadership and management; performing regular annual self-evaluation; accrediting training programs, ensuring capable leadership and management,. The 2009 higher education proclamation provides legal framework for the establishment of a private institution with minimum capacity and with a similar status as that of well-established and highly organized ones. All private higher education institutions are subject to accreditation every five years by the Ministry of Education (ST1, 2016).

The other issue regarding the public-private divide is related to student recruitment and admission policies and practices. The playground is not equal for public and private higher education institutions to compete for incoming students. Private higher education institutions cater a tiny proportion of students who are unable to join public higher education institutions due to their low performance in national university entrance examinations. This indicates that the private higher education sector plays demand absorbing role in terms of taking up the demand that cannot be met by the public higher education institutions. In other words, competition within and between public and private higher education institution is constrained by the fact that the private institutions cannot determine the quantity and quality of students they enroll. Putting differently, students' choice of institutions is restricted by the admission policies and application systems set by the Ministry of Education. In this regard, one of the interviews from the private higher education argues that private higher education institutions are playing an important role in opening up access for students who might not get a place in the public intuitions particularly female students; providing market-friendly programs and opening employment opportunities. This is a major challenge for private higher education institutions to attract the required number and type of students appropriate to their own programs and customer profiles.

The inability to compete for incoming students and attract the best and appropriate candidates makes it difficult for private higher education institution in providing quality education. One of the major issues regarding private higher education has been poor quality of education. Analysis of the existing documentary evidences show that despite their 
apparent contributions in improving access to higher education and human resource development of the country, however, the quality and relevance of the courses offered by the private providers has been a point of debate among stakeholders. Particularly, the government has also been blaming some of the private higher education institutions as degree mills because of their low quality graduates and few were abandoned licenses. In fact, it is a challenge for the private higher education institutions to produce quality graduates by enrolling those students who cannot join public institutions due to their poor performance in the national university entrance exams. Results of the interview data shows mixed views among the respondents regarding quality and relevance of private higher education institutions. For example, one of the interviewees from the Ministry of education responded as follows

\begin{abstract}
There are many private higher education institutions that compromise quality in favor of profit making. Majority of the private institutions focus on their business motive. The quality and relevance of programs in most of the private higher education institutions is questionable in terms of the current 70/30 government policy, except those universities and colleges engaged in health, science and technology training programs. Most of the private higher education institutions focus in programs that do not require investment in science and technology infrastructure and facilities viz., humanities \& social sciences, business and economics followed by few programs in computer science and technology (ME1, 2016).
\end{abstract}

Similarly, majority of the interviewees from the public higher education institutions argue that most of the private higher education institutions have problems concerning the provision of relevant and quality education and it is difficult to put the level of satisfaction with regard to the current performance of private higher education institutions in terms of addressing stakeholders' expectation. However, many of the interviewees from the private higher education institutions witnessed that they balance between their business motive and stakeholders needs. In this regard, one of the interviewees from the private institutes argues as follows.

Most of our programs are relevant to the labor market and students' needs. The concern regarding quality of education is not unique to private higher education institutions. It is a national concern including the public higher education institutions and the government at large. Unlike the public ones, our programs are subject to accreditation. Our main focus is whether students have got what they should for the money they paid. So we think that our institution is primarily educational institution and then business institution. Our business motive focuses on a long-term interest.
The income we collect from the students is very minimal to attract the financially unable and low income students (MPHE2, 2016).

The results in the preceding paragraphs point to the fact private higher education institutions are playing significant role in bridging the class divide and gender disparity by providing access to those who are unable to meet the admission criteria for public higher education institutions due to their low performance in university entrance examination and attracting a significant proportion of female students. The issue of relevance and quality is a national concern that includes both private and public higher education institutions and the public at large.

Results of the documentary analysis revealed that lack of policy incentive is the other major challenge for private higher education institutions. With regard to incentives, the 2009 higher education proclamation stipulates some provisions of government subsidy for private higher education institutions in terms of capacity building support for non-profit making private institutions that strive to strengthen the preparation of good quality graduates based on certain preconditions [25]. However, findings show that government support for private higher education institutions in terms of budget subsidy and student loans is almost non-existent, though the higher education proclamation allows the opening and functioning of PHEIs in the country. As it stands today, most of the Ethiopian private higher education institutions rely on students' fees for their survival. The lack of competition for students together with the absence of policy incentives in terms of subsidy restricts most private higher education institutions to focus on vocationally and commercially oriented, market friendly and low cost programs and courses in areas that don't require more investment on educational inputs.

The findings from the preceding paragraphs suggest that the public-private dynamism is constrained by many challenges related to policy and regulation, quality and relevance, student admission and policy incentives. This in turn limits the huge potential contribution of the private sector in addressing the increasing social demand for higher education and the need for quality human resource for the emerging economy. Further analysis of documentary data is conducted to examine the influence of the legal and regulative framework on the public-private divide in the Ethiopian context.

\subsection{The Influence of Legal and Policy Frameworks on the Public-Private Divide}

In the Ethiopian context, both public and private higher education institutions operate under a common institutional setting in which the legal and policy framework plays a major role. Both sectors are governed by the same legal framework-the 2009 higher education proclamation related to policy directives and regulatory organs. There is no a separate law for private higher education institutions. The 
2003 higher education proclamation, which was modified in 2009 , provides the legal ground for the establishment and functioning of public and private higher education institutions in the country. The proclamation stipulates the requirements, autonomy, governance and accountability regarding the establishment and operation of higher education institutions in general and private higher education institutions in particular. As clearly indicated in the proclamation, private higher education institutions are required to strictly comply the provisions and requirements of the proclamation and other policy directives provided by the Ethiopian Ministry of Education regarding student admission, programs and curricula, quality assurance and accreditation, leadership and governance, and accountability. In this regard, many issues and concerns have been raised by the private institutions on how the proclamation is exercised and translated into action across public and private higher education institutions.

In practice, private higher education institutions are subject to accreditation of their programs, whereas the public ones are not required to do so under the same proclamation. Similarly, all public universities depend on government for about $90 \%$ of their expenditure regardless of evidences of the provision of quality education, whereas the private ones do not receive government subsidy or incentives. Majority of the respondents from private higher education institutions pointed that the private higher education institutions have no equal chance to compete for incoming students, but they are expected to fulfill the requirements for quality and relevance stipulated in the proclamation. In this regard, one of the interviews from private institutions asserted that government policies and regulatory frameworks favor public HEIs, the private HEIs are negatively affected by government policies and regulatory frameworks, and there are implementation problems of government policies concerning private HEIs. Similarly, other respondents also argue that, under such circumstances, it is difficult for the private higher education institutions to compete with the public ones in terms of addressing the unmet social demand for access, while improving quality of their provision.

It is apparent from the preceding paragraphs that the rule of the game is not the same for public and private higher education institutions. Putting it differently, the playground does not allow a healthy competition among public and private providers in terms of access, quality and relevance of education. These issues obviously have a negative impact on the development of the higher education of the country in general and the growth and smooth functioning of the private sector in particular. This in turn has an implication to the benefits of higher education to the society in terms of addressing the increasing social demand for quality higher education. The main issue here is how the existing legal and policy framework could be implemented in terms of maximizing the benefits of both public and private sectors to society.

\section{Conclusions and Implications}

In this article an attempt was made to understand the public-private divide in the Ethiopian higher education landscape based on secondary sources of data and key informant interviews. It critically examines issues related to regulatory frameworks and incentives in order to understand the public-private divide in the Ethiopian higher education context. The findings in this article show that there have been rapid changes in the social environment of the Ethiopian higher education that have brought huge demand for human resource capacity building. This has resulted in the rapid change of the higher education landscape including, among others changes in size and shape-the increase in the number of public universities and the introduction of private institutions, rapid enrolment expansion, and a shift in focus in favor of science and technology fields. This article demonstrated that the private higher education institutions have been playing significant role in addressing the unmet social demand for higher education through increasing access for those unable to meet admission criteria for public institutions, particularly female students and thereby creating employment opportunities.

However, the findings revealed that private higher education institutions are constrained by a multitude of problems and challenges related to student admission, quality and relevance, policy incentives and regulatory frameworks compared to the public ones. Notably, the existing playground/rule of the game is not fairly treating both public and private providers in terms of student recruitment, quality regulation and other policy incentives. It is argued that a right balance between the public-private divide is necessary to ensure a healthy competition among the higher education institutions in terms of quality and relevance. This requires creating a fair and robust legal and regulatory framework and policy incentives to maximize the benefits of both public and private providers in terms of addressing the increasing demand for quality and relevant higher education in the country. The main issues/focus of the legal and policy framework should be on how to ensure a vibrant and competitive higher education system that addresses the trained labor force and knowledge demand of the economy. This suggests the need to focus on ensuring the relevance and quality of education and research produced by higher education institutions regardless of their being public or private. The government should also ensure a regulatory system that provides the right balance between protecting the public and encouraging private providers to invest on quality education. Finally, the rule of the game should be on what the relevance and quality of the outputs are, and to what extent the public will benefit from higher education rather than on what is public or private. 


\section{REFERENCES}

[1] Geiger, R. L, Finance and Function: Voluntary and Diversity in American Private Higher Education. In D.Levy (ed.). Private Education: Studies in Choice and Public Policy New York and Oxford University Press, 1986.

[2] Levy, D.C., 'Private' and 'Public' Analysis in Higher Education. In D.Levy (ed.). Private Education: Studies in Choice and Public Policy New York and Oxford University Press, 1986.

[3] Bernasconi, A. A, Legal Perspective on "Privateness" and "Publicness" in Latin American Higher Education,2011, Journal of Comparative Policy Analysis: Research and Practice, 13:4. 351-365.

[4] Marginson, S, The public/private division in higher education: A global revision, 2007, Higher Education, 53, 307-333.

[5] Enders, J. \& Jongbloed, B., Public-Private Dynamics in Higher Education: Expectations, developments and outcomes, 2007, Bielefeld: Transcript Verlag.

[6] Marginson, S. Higher Education in East Asia and Singapore: Rise of the Confucian Model, 2011, Higher Education, 61 (5), 587-611

[7] Marginson, S. and Sawir E. Interrogating global flows in higher education, 2005, Globalisation, Societies and Education 3(2)

[8] Levy, D.C. The Unanticipated Explosion: Private Higher Education's Global Surge, 2006, Comparative Education Review, 50(2)

[9] Geiger, R.L, Private Higher Education: In International Higher Education: An Encyclopedia, Edited by Altbach, P.G. New York: Garland Publishing, 1991.

[10] Levy, D.C, 'A Comparison of Private and Public Educational Organizations. In Walter W (ed.). Handbook on Non-Profit Organizations: Between the Private and the Public, 1987, Yale University Press

[11] Teixeira, P. \& Amaral, A, Private higher education and diversity: an exploratory survey, 2001, Higher Education Quarterly, 55.

[12] Prokhor, I, The growth and decline of private higher education in Ukraine: Implications for equity and quality, 2015, International Journal of Economics and Society, 1.
[13] Geiger,R.L Public and private sectors in higher education: A comparative international pattern, 1988, Higher education, 17(6):699-711.

[14] Sabatier, P. A. Toward better theories of the policy process, 1991. Political Science and Politics, 24(2), 147-156.

[15] Pachuashvili, M, Governmental Policies and Their Impact on Private Higher Education Development in Post-communist Countries, 2011, Journal of Comparative Policy Analysis, 13.

[16] Kinser, K. Introduction, 2019. ASHE Higher Education Report, 36(3), 1-7.

[17] Shah, M., \& Nair, C. S. (2013). Private for-profit higher education in Australia: widening access and participation and opportunities for public-private collaboration. Journal of Higher Education Research and Development, 32(8), 820832.

[18] Bergan, S, Higher education as a "public good and public responsibility": what does it mean? Council of Europe Publishing: Council of Europe, 2005

[19] Bjarnason S. et al. 2009. A new dynamic private higher education. Paris: UNESCO.

[20] Alon, S. (2009). The Evolution of Class Inequality in Higher Education: Competition, Exclusion, and Adaptation. American Sociological Review, Vol. 74

[21] Bowen, William G.. "Extending Opportunity: What Is To Be Done?" In College Access: Opportunity or Privilege?, edited by S. M. McPherson and M. O. Schapiro, 2006. New York: The College Board.

[22] Helena, M. The State and the Market in the Regulation of Higher Education in Brazil, 2003. In Colin Brock and Simon Schwartzman, (eds.), the Challenges of Education in Brazil. Oxford

[23] MoFED, Growth and Transformation Plan (GTP) 2010/11-2014/15, Addis Ababa: Federal Democratic Republic of Ethiopia, 2010.

[24] MoE, Education Statistics Annual Abstract, Addis Ababa: Federal Democratic Republic of Ethiopia, 2016

[25] FDRE, Higher Education Proclamation (No. 650/2009), Addis Ababa: Birhanena Selam Printing Enterprise, 2009. 